\title{
Multi-Biomarker Assessment in Common Carp (Cyprinus carpio, Linnaeus 1758) Liver after Acute Chlorpyrifos Exposure
}

\author{
Stela Stoyanova ${ }^{1}$, Elenka Georgieva ${ }^{1, *}$, Iliana Velcheva ${ }^{2}$, Ilia Iliev ${ }^{3}$, Tonka Vasileva ${ }^{3}$, \\ Veselin Bivolarski ${ }^{3}$, Stoil Tomov 4 , Krisztián Nyeste ${ }^{5,6}$, László Antal ${ }^{5, *(D)}$ and Vesela Yancheva ${ }^{2}$ \\ 1 Department of Developmental Biology, Faculty of Biology, Plovdiv University, 4000 Plovdiv, Bulgaria; \\ stela.st@abv.bg \\ 2 Department of Ecology and Environmental Conservation, Faculty of Biology, Plovdiv University, \\ 4000 Plovdiv, Bulgaria; anivelcheva@abv.bg (I.V.); veselayancheva@yahoo.com (V.Y.) \\ 3 Department of Biochemistry and Microbiology, Faculty of Biology, Plovdiv University, 4000 Plovdiv, \\ Bulgaria; ilievini@abv.bg (I.I.); tonika1@abv.bg (T.V.); vb_ski404@zohomail.eu (V.B.) \\ 4 Department of Urology and General Medicine, Plovdiv Medical University, 4000 Plovdiv, Bulgaria; \\ stoiltomov57012@gmail.com \\ 5 Department of Hydrobiology, University of Debrecen, 4032 Debrecen, Hungary; \\ nyeste.krisztian@science.unideb.hu \\ 6 Pál Juhász-Nagy Doctoral School of Biology and Environmental Sciences, University of Debrecen, \\ 4032 Debrecen, Hungary \\ * Correspondence: e_tomova@abv.bg (E.G.); antal.laszlo@science.unideb.hu (L.A.)
}

Received: 18 May 2020; Accepted: 24 June 2020; Published: 26 June 2020

\begin{abstract}
The excessive use of pesticides at different stages of crop production can pose a great danger to the aquatic environment, and particularly to fish. The purpose of the present work was to assess the negative effects of chlorpyrifos (CPF) on the liver histological architecture and the activities of marker enzymes in common carp (Cyprinus carpio Linnaeus, 1758), by applying a multi-biomarker technique. The tested insecticide is categorized as a priority pollutant in surface waters in terms of Directive 2013/39/EU. The carps were exposed to different and environmentally relevant $\mathrm{CPF}$ concentrations for $72 \mathrm{~h}$ (a short-term acute experiment). The results showed that the tested insecticide alters the liver histological structure, causing degenerative lesions, such as granular and vacuolar degeneration; necrobiotic alterations and necrosis, as well as changes in the circulatory system. In addition, CPF induces changes in the enzymatic activity of lactate dehydrogenase $(\mathrm{LDH})$, aspartate aminotransferase (ASAT), alanine aminotransferase (ALAT), cholinesterase (ChE), glutathione peroxidase (GPx) and catalase (CAT). The results from such experimental set ups could be successfully used in the legislation related to the protection of water bodies from contamination, in areas with intensive application of plant protection products used in agricultural practices, and also in implementing the Water Frame Directive by using multi-biomarker approaches.
\end{abstract}

Keywords: fish; liver; histology; enzymatic activity; pesticides

\section{Introduction}

Modern agricultural practices lead to the indiscriminate use of various pesticides that will eventually enter the aquatic environment [1]. Chlorpyrifos (CPF, O,O-diethyl O-3,5,6-trichloro-2-pyridyl-phosphorothioate) is a broad spectrum organophosphorus insecticide (OP) applied to control agricultural and domestic pests [2,3]. In addition, CPF is one of the most widely used agricultural insecticides throughout the world, accounting for $50 \%$ of global insecticidal use $[4,5]$. 
There are many pathways by which CPF can be distributed throughout aquatic ecosystems [4]. CPF can enter to aquatic ecosystems through rainfall, runoff and air-drift [5]. Wood and Stark [6] explain that areas treated with CPF can result in concentrations of up to $4.3 \mu \mathrm{g} / \mathrm{L}$ in watercourses and lakes. For example, CPF is one of the most widely used organophosphorus insecticides in Argentina, and it is reported that concentrations of CPF have reached $10.8 \mu \mathrm{g} / \mathrm{L}$ in the surface waters of Pampa Ondulada, Argentina [7]. CPF usage has the potential to change the aquatic environment, affecting the boundary of tolerance of the aquatic ecosystems. Furthermore, $\mathrm{CPF}$ is one of the most common pesticides found in fishery products in China [8].

Pesticide resistance, as well as bioaccumulative and toxic characteristics, cause severe short- and long-term effects, even in low concentrations, and most of these toxic compounds could also accumulate significantly in aquatic organisms [9]. Among all species of aquatic organisms, fish are regarded as good indicators for assessing the quality of aquatic ecosystems [10]. Acute toxicity tests involving fish species have proven to be useful for ecotoxicological evaluation to assess the potential hazards of various chemical contaminants, e.g., pesticides [11-13]. Common carp (Cyprinus carpio Linnaeus, 1758) is one of the most widespread fish species in the temperate regions of the world [14]. Common carp is very popular in aquaculture industries, due to several specific features e.g., its feeding habits, high growth rate, reproduction in captivity, adaptation to commercial diets and density. Moreover, common carp is relatively insensitive, and can survive and accumulate contaminants at heavily polluted sites, which is why it is used as a freshwater bioindicator in environmental toxicology [15]. However, anthropogenic activities and environmental pollutants can be harmful for the physiology of common carp [16-21].

$\mathrm{CPF}$ can cause acute poisoning, and is reported to be involved in multiple mechanisms which cause hepatic dysfunction, genotoxicity, and neurobehavioral and neurochemical changes [3,22,23]. $\mathrm{CPF}$ can also inhibit the acetylcholinesterase enzyme causing accumulation of acetylcholine in the cholinergic receptors of nervous systems [3]. According to Banaee [24], under conditions of stress, fish need extra energy, thus lactate dehydrogenase (LDH) is then involved in energy production via anaerobic metabolism. In addition, as stated by Guptha et al. [25] and Ghorpade et al. [26], under conditions such as those caused by pesticides, the changes in aspartate aminotransferase (ASAT) and alanine aminotransferase (ALAT) enzymatic activity stimulate the process of gluconeogenesis and the mobilization of L-amino acids.

Furthermore, oxidative stress is a general molecular mechanism in OP-induced toxicity [27]. However, fish have several defensive mechanisms to neutralize the impact of reactive oxygen species (ROS) caused by OP-induced toxicity [3]. These include various antioxidant defense enzymes, e.g., catalase (CAT) and glutathione peroxidase (GPx), whose activities can be decreased significantly by CPF intoxication. ROS which are not neutralized by the antioxidant defense system can cause changes in the fish organism at the cellular, tissue and organ level [28,29]. Therefore, in recent years, considerable research has focused on pesticide induced oxidative stress as a possible mechanism of toxicity $[3,30]$.

The liver is an organ that is widely used in biomarker approach studies on fish health assessment, and is associated with detoxification processes, due to its function, position and blood supply. It is also one of the most affected organs in contaminated waters, but also plays an important role in fish physiology, i.e., in anabolism (proteins, lipids, carbohydrates) and catabolism (glycogenolysis, detoxification), and is a storage center for different substances, mainly glycogen [31]. In addition, the parenchymal liver tissue in fish has important physiological functions, such as the detoxification of chemical contaminants (e.g., pesticides) [32].

Histology is a non-specific, relatively low-cost and valuable ecological risk assessment method [33]. Furthermore, changes in the activity of antioxidant enzymes can also be considered a reliable biomarker for toxic damage $[34,35]$. Generally, biochemical alterations occur before the presence of the pathological changes in the tissue [36]. In addition, the inhibition of enzymatic activity is also used to indicate tissue damage [37]. Pesticides can produce free oxygen radicals via several mechanisms, i.e., interference with electronic transport of reactive intermediates, the depletion of non-enzymatic antioxidants, inactivation 
of antioxidant enzymes and membrane lipid peroxidation [38,39]. The activity of the enzymes varies in the different tissues, being higher in organs with high oxidative potential (e.g., in the liver) [37].

Based on the excessive use of pesticides and their negative impact on the aquatic environment (e.g., [40]), the main aim of the present study is to determine the effects of environmentally relevant and decreasing CPF concentrations on common carp, which is one of the most common freshwater species in aquaculture and an important test organism in toxicology. Therefore, for this purpose, we applied a multi-biomarker approach to assess the negative effects of CPF. We observed the histological structure and measured the enzymatic activity of lactate dehydrogenase (LDH), aspartate aminotransferase (ASAT), alanine aminotransferase (ALAT), cholinesterase (ChE), glutathione peroxidase (GPx) and catalase (CAT) in the liver of the tested fish species.

\section{Materials and Methods}

\subsection{Chemicals}

Chlorpyrifos (CPF, CAS: 2921-88-2) with a density of $0.7688 \mathrm{~g} / \mathrm{cm}^{3}$ at $21.3^{\circ} \mathrm{C}$ and a purity of $99.5 \%$, diluted in cyclohexane was purchased for the purpose of this study. Stock solution of $0.03 \mu \mathrm{g} / \mathrm{L}$ (30 ppm) CPF was prepared. Thereafter, $30 \mu \mathrm{L}$ of it was diluted in $970 \mu \mathrm{L}$ cyclohexane (100 ppm) and calculated for the tested concentrations relatively for $100 \mathrm{~L}$ aquaria. All other applied chemicals for histological and biochemical analyses were of analytical grade and were obtained from MERCK (Darmstadt, Germany). They were used as received, without any further purification.

CPF is a degradable pesticide and it undergoes breakdown in the environment as a result of biological, chemical and physical forces. In all systems (soil, water, plants and animals), the major pathway of degradation begins with cleavage of the phosphorus ester bond to yield the breakdown product trichloropyridinol (TCPy) [9]. This first step is a detoxification, as TCPy has no insecticidal activity, and is considered toxicologically insignificant by regulatory authorities. In soil and water, TCPy is further degraded via microbial activity and sunlight to carbon dioxide and organic matter. In animals, TCP may be excreted directly or following conjugation (bonding with other chemicals); in plants TCP conjugates are stored [13].

The solubility of $\mathrm{CPF}$ is temperature dependent, but at $25^{\circ} \mathrm{C}$, it is about $1.4 \mathrm{mg} / \mathrm{L}$. In water, CPF readily adsorbs to suspended sediment and bottom materials. Volatilization is probably the primary route of loss of CPF from water. Volatility half-lives of 3.5 and 20 days have been estimated for pond water [41]. Its change into other natural forms (biotransformation) is slow [37]. Research suggests that this insecticide is unstable in water, and the rate at which it is hydrolyzed increases with temperature, decreasing by 2.5 to 3 -fold with each $10^{\circ} \mathrm{C}$ drop in temperature. The rate of hydrolysis is constant in acidic to neutral waters, but increases in alkaline waters. In water at $\mathrm{pH} 7.0$ and $25{ }^{\circ} \mathrm{C}$, it is estimated to have a half-life of 35 to 78 days [37].

\subsection{Animals and Treatments}

Healthy common carp specimens $(n=200)$, with normal morphology and no outside alterations were obtained from the Institute of Fisheries and Aquaculture, Bulgaria, where the conditions are controlled and strictly followed on a daily basis. The common carp had approximately the same size (mean total length $13.5 \pm 2.5$ (SD) cm; mean body mass $22.5 \pm 3.5$ (SD) g). After transportation, they were placed in $100 \mathrm{~L}$ glass aquaria with chlorine free tap water to acclimatize for seven days. The photoperiod was $12 \mathrm{~h}$ light and $12 \mathrm{~h}$ dark. During the acclimatization period, the fish were fed with commercial pellets for Cyprinids (CarpCo Excellent Koi Grower, Helmond, The Netherlands), but they were not fed 2 days prior to the experimental exposure [42].

After this adaptation period, the fish were divided into four tested groups $(n=15)$, including a control group (chlorine free tap water) and were treated in static conditions for $72 \mathrm{~h}$ with nominal and environmentally relevant concentrations of CPF [40]. The experimental set up was performed in triplicate. The tested insecticide was added only at the beginning of the experiment and the water 
was not renewed, as explained in other studies [43-45]. In addition, the half-life of CPF in water ranges from 3.5 to 20 days and 35 to 78 days, depending on the $\mathrm{pH}$, as described above; therefore, it was supposed that the concentrations of CPF would not decrease considerably during the present experimental design of $72 \mathrm{~h}$. No control with cyclohexane only was used, as its concentration was extremely low and no effect was expected.

The tested decreasing CPF concentrations were based on EU legislation and made up as 50 and $30 \%$ of the allowable annual average concentrations (AA-EQS) in surface waters $(0.03 \mu \mathrm{g} / \mathrm{L})[40,43]$. Thus, the applied insecticide concentrations were $0.03 \mu \mathrm{g} / \mathrm{L}, 0.015 \mu \mathrm{g} / \mathrm{L}$ and $0.009 \mu \mathrm{g} / \mathrm{L}$. A multi-parameter portable meter (MultiLine ${ }^{\circledR}$ Multi 3510 IDS, WTW-Xylem Analytics, Weilheim, Germany) was used, in order to measure the basic physico-chemical characteristics of water, including its conductivity, dissolved oxygen, $\mathrm{pH}$ and temperature. They were monitored three times at the 24th, 48th and 72nd h [46]. Directive 2010/63/EU regarding the protection of animals used for scientific purposes was followed thoroughly; hence, it was ensured that the fish were sacrificed with minimum pain, suffering and distress. For this purpose, an anesthetic overdose was applied (100 mg/L water of Tricaine methanesulfonate (MS222) (Argent Chemical Laboratories, Redmond, WA, USA)) and, thereafter, the fish were dissected, and the samples were collected for different subsequent analyses. Furthermore, the common carps were dissected according to the international procedures given by Rosseland et al. [47], and the methods were approved by the Ethics Committee at the Faculty of Biology, Plovdiv University, Bulgaria (No. 4/10.09.2019). An additional clarification, which we must make, is that the main distinguishing anatomical feature of common carp from other Cyprinid fish is the presence of hepatopancreas, which is a mixture between a liver and a pancreas. For the purpose of this study we adopted the term "liver", which also appears in the scientific literature.

\subsection{Histological Procedures}

A standard histological method involving hematoxylin-eosin staining was followed [48]. All histological samples were prepared for light microscopy analysis [48]. For each fish, the liver was sampled and fixed in 10\% neutrally buffered formaldehyde for $24 \mathrm{~h}$. The preserved samples were rinsed in tap water, dehydrated in a series of solutions with increasing ethanol concentrations $(70 \%$, $80 \%, 85 \%, 96 \%, 100 \%$, respectively). Then they were cleared in xylene, infiltrated with liquid paraffin with a melting point of $54-56^{\circ} \mathrm{C}$ and finally embedded in paraffin wax. The tested organs from each fish were sampled using a rotary microtome (Leica RM 2125 RTS, Leica Microsystems, Wetzlar, Germany); sections of $5 \mu \mathrm{m}$ were stained with hematoxylin-eosin (H\&E) and investigated with a light microscope (Leica DM 2000, Leica Microsystems, Wetzlar, Germany).

\subsection{Semi-Quantitative Screening}

The histological alterations were presented according to the semi-quantitative system described by Bernet et al. [49], which we adopted for the purposes of the study, but also modified slightly. According to Saraiva et al. [50], a five-degree (0-5) severity gradation scale (SGS), which represents the severity of each alteration, was applied. In addition, the organ index values $\left(\mathrm{I}_{\mathrm{O}}\right)$ (circulatory disturbances $\left(\mathrm{I}_{\mathrm{LC}}\right)$, regressive lesions $\left(\mathrm{I}_{\mathrm{LR}}\right)$, progressive lesions $\left(\mathrm{I}_{\mathrm{LP}}\right)$, and inflammation $\left(\mathrm{I}_{\mathrm{LI}}\right)$ ) were calculated, in order to classify the severity of the histological response using classes based on the scoring scheme suggested by Zimmerli et al. [51]: Class I (index $\leq 10$ )—normal hepatic tissue structure with slight histological alterations; Class II (index 11-20)—normal hepatic structure with moderate histological alterations; Class III (index 21-30)—moderate modifications of normal hepatic tissue; Class IV (index 31-40)—pronounced histological alterations of the liver; Class V (index N 40)-severe histological alterations of the liver. We also aimed to study the prevalence of liver histological changes. Therefore, this was calculated as the percentage occurrence within the total number of examined slides $(n=10)$ per individual. 


\subsection{Biochemical Analysis}

The liver samples were quickly thawed on ice and homogenized using a PYREX' ${ }^{\text {TM }}$ Potter-Elvehjem tissue grinder with PTFE pestle (Thermo Fisher Scientific, Waltham, MA, USA) in a chilled phosphate $(50 \mathrm{mM}, 300 \mathrm{mM} \mathrm{NaCl}, \mathrm{pH}=7.4)$ buffer [52]. The protein levels were measured by the Bradford [53] method with Coomassie Brilliant Blue G-250, using bovine serum albumin at absorbance of $595 \mathrm{~nm}$, and presented as milligram protein per milliliter homogenate. The enzymatic activities of lactate dehydrogenase (LDH, EC 1.1.1.27), aspartate aminotransferase (ASAT, EC 2.6.1.1), alanine aminotransferase (ALAT, EC 2.6.1.2), cholinesterase (ChE, EC 3.1.1.8), glutathione peroxidase (GPx, EC 1.11.1.9) and catalase (CAT, EC 1.11.1.6) were measured spectrophotometrically, using a Beckman Coulter Spectrophotometer DU 800 (Beckman Coulter, Inc., Brea, CA, USA) at $25^{\circ} \mathrm{C}$. The LDH activity was analyzed according to Vassault [54]. The ASAT and ALAT activities were determined using the method described by Reitman and Frankel [55]. The ChE activity was analyzed by the method developed by Burtis-Ashwood [56]. The CAT and GPx activities were determined using the method described by Wendel [57].

\subsection{Statistical Tests}

IBM SPPS Statistics for Windows (Version 20.0, IBM Corp., Armonk, NY, USA) and GraphPad Prism 7 for Windows (GraphPad Software, San Diego, CA, USA) were used for statistical analysis of the data. The histological index results, percentage prevalence and enzymatic activities were expressed as averages. The normal distribution was tested with the Shapiro-Wilk test. The homogeneity of variances was tested with the Levene's test, respectively. The results were also analyzed for significance of differences between the control and treated groups by one-way analysis of variance (ANOVA), followed by Tukey's test (means comparison). The significance of results was set at $p<0.001,0.01$ and 0.05 .

\section{Results}

\subsection{Water Quality Parameters}

The basic physico-chemical properties, such as conductivity, dissolved oxygen, $\mathrm{pH}$ and temperature, were kept relatively constant during the exposure period (Table 1) (see [40]). The control results did not differ significantly (ANOVA, $p>0.05$ ), compared to the tested aquaria.

Table 1. Basic water properties measured in three chlorpyrifos (CPF) test tanks and control, according to Yancheva et al. [40].

\begin{tabular}{cccccc}
\hline Test Tank & $\mathbf{p H}$ & $\mathbf{T}\left({ }^{\circ} \mathbf{C}\right)$ & $\begin{array}{c}\text { Conductivity } \\
(\mu \mathrm{S} / \mathbf{c m})\end{array}$ & $\begin{array}{c}\text { Dissolved } \\
\text { Oxygen }(\mathbf{m g} / \mathrm{L})\end{array}$ & $\begin{array}{c}\text { Dissolved Oxygen } \\
\text { Saturation }(\%)\end{array}$ \\
\hline Control & $8.3 \pm 0.5$ & $16.5 \pm 1.5$ & $370 \pm 5.5$ & $8.5 \pm 1.5$ & $86.99 \pm 12.82$ \\
$0.009 \mu \mathrm{g} / \mathrm{L} \mathrm{CPF}$ & $8.0 \pm 0.5$ & $17.3 \pm 2.0$ & $365 \pm 3.5$ & $8.3 \pm 0.3$ & $86.38 \pm 3.02$ \\
$0.015 \mu \mathrm{g} / \mathrm{L} \mathrm{CPF}$ & $7.5 \pm 1.5$ & $18.5 \pm 0.5$ & $410 \pm 0.5$ & $7.0 \pm 0.5$ & $74.67 \pm 5.38$ \\
$0.030 \mu \mathrm{g} / \mathrm{L} \mathrm{CPF}$ & $8.5 \pm 0.5$ & $19.0 \pm 0.5$ & $353.3 \pm 0.3$ & $9.1 \pm 1.0$ & $98.06 \pm 10.55$ \\
\hline
\end{tabular}

\subsection{Liver Histological Structure}

The results from the conducted histological study are presented in Tables 2 and 3, as well as Figures 1 and 2. In the control group, we observed relatively normal liver morphology (Table 2, Figure 1A). The hepatic structure was characterized by compactly arranged hepatocytes disposed in a simple layer aligned with sinusoids. The parenchyma itself was primarily composed of polyhedral hepatocytes, typically with central nuclei, with densely stained chromatin margins and a prominent nucleolus. We also observed the pancreatic mass, which was situated around the branches of hepatic portal veins. In addition, the pancreatic mass consists of two parts, which are the exocrine and endocrine. Exocrine cells are larger and elongated, while endocrine cells are smaller and round. The morphology 
of the exocrine cells shows that they are arranged in an acinus form with a distinct nucleus, while the endocrine cells are scattered in between the hepatic portal veins and the exocrine pancreas. Moreover, the venous blood entered the liver caudally from the intestine via the hepatic portal veins, and branches into capillaries known as sinusoids; the sinusoids were lined with reticuloendothelial cells, which were in turn surrounded by hepatocytes (see [58]).

With regard to the regressive liver lesions (Table 2), we found granular (Figures 1B and 2B) and vacuolar degeneration (Figure 1D) in the highest degree of expression. As shown in Table 2, all concentrations induced the same level of granular degeneration. Moreover, vacuolar degeneration showed a tendency towards an increase in the degree of expression with the increased CPF concentrations. We did not find fatty degeneration in the hepatocytes (Tables 2 and 3). Necrobiotic changes, such as karyolysis, karyorrhexis and karyopyknosis (Figure 2D) were found mainly in a mild form of expression. At the higher CPF concentration, these changes were expressed in a moderate degree, which, in turn, demonstrates the highest degree of degenerative processes leading to necrosis. In addition, we also found necrosis in a moderate degree at the highest CPF concentration (Figure 2C). We also observed structural alterations in the interstitial tissue in a mild degree of expression. With regard to the progressive alteration in the common carp liver, we observed hypertrophy in a mild degree at the lower CPF concentrations, while, at the highest concentration, this histological lesion was expressed in a moderate degree.

The changes that occurred in the circulatory system were expressed on the one hand, in hyperaemia (see Figure 1C), the grade of which was determined by the proposed assessment scale as moderate at the higher tested concentrations, while, at the lowest concentration, this lesion was absent (Table 2). On the other hand, we found inflammation, which was expressed as lymphocytic proliferation in the parenchyma. It was found only at the highest applied CPF concentration to be at a mild degree of expression.

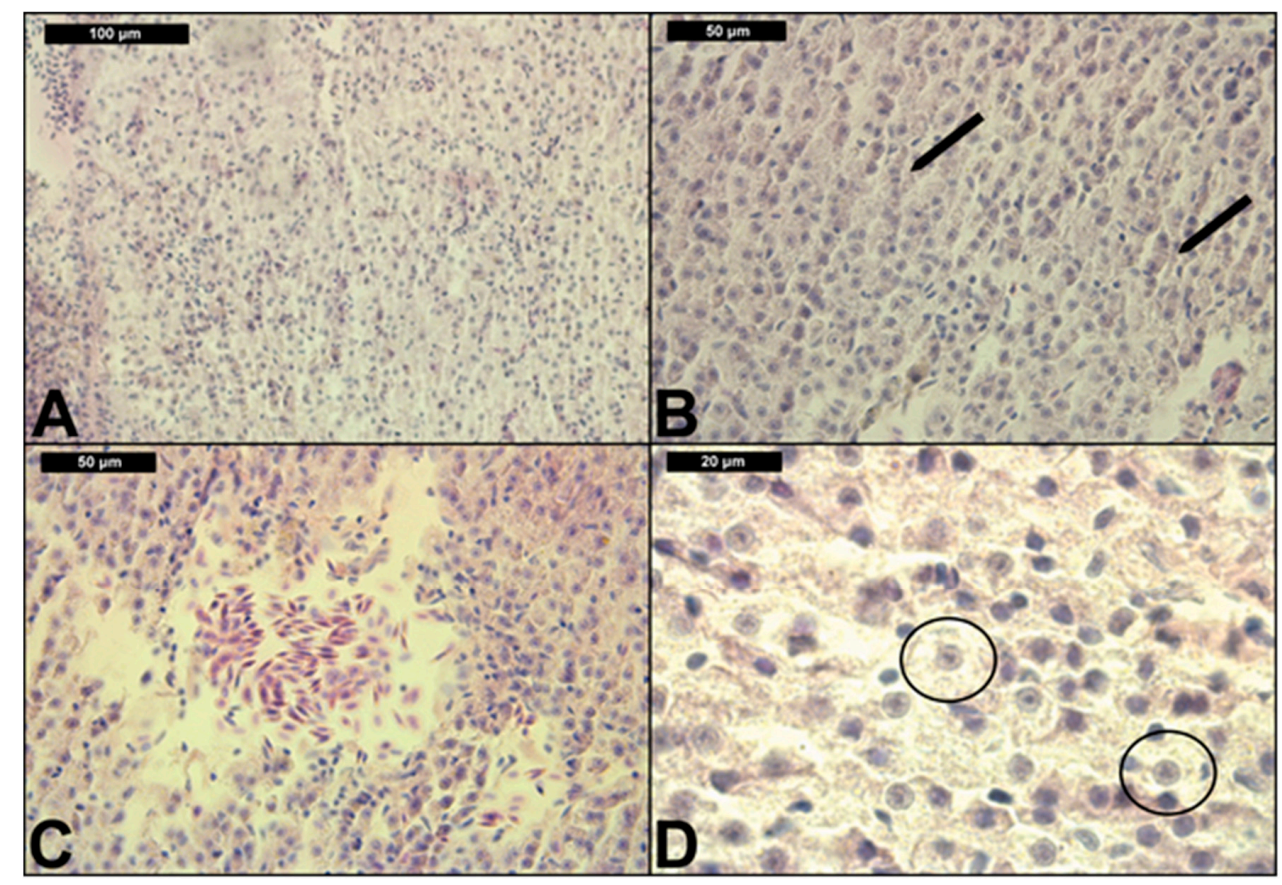

Figure 1. Histopathological alterations in the liver of common carp after the exposure with decreasing CPF concentrations based on Directive 2013/39/EU of the European Parliament and of the Council. (A) Normal histological structure of carp liver (scale bar $100 \mu \mathrm{m}$ ) hematoxylin-eosin (H\&E); (B) granular degeneration in carp liver at $0.009 \mu \mathrm{g} / \mathrm{L} \mathrm{CPF}$ (scale bar $50 \mu \mathrm{m}$ ) H\&E; (C) hyperaemia in carp liver at $0.015 \mu \mathrm{g} / \mathrm{L} \mathrm{CPF}$ (scale bar $50 \mu \mathrm{m}$ ) H\&E; (D) vacuolar degeneration in carp liver at $0.015 \mu \mathrm{g} / \mathrm{L} \mathrm{CPF}$ (scale bar $20 \mu \mathrm{m}) \mathrm{H} \& \mathrm{E}$. 
The indices of histological changes highlight the distribution frequency of alterations and the state of damage of the studied organ. In addition, the indices of histological changes showed that the regressive lesions were the most severe alterations observed in the liver parenchyma at all tested concentrations. Moreover, $\mathrm{I}_{\mathrm{LR}}$ was significantly higher $(p<0.05)$ than the other indexes $\left(\mathrm{I}_{\mathrm{LC}}, \mathrm{I}_{\mathrm{LP}}, \mathrm{I}_{\mathrm{LI}}\right)$. In terms of the percentage prevalence, we observed the highest percent of histological alteration at the highest CPF concentrations (Table 3). Unlike the regressive, progressive and circulatory changes, which showed a higher prevalence, the inflammation disturbances were observed less frequently, and only at the highest CPF concentration (see Table 3). According to the overall organ index, it was found to be categorized as Class III (index 21-30)—moderate modifications of normal tissue at the highest CPF concentration; it was also statistically higher (ANOVA F $=6.123, p<0.05$ ), compared to the organ index at the other two tested concentrations.

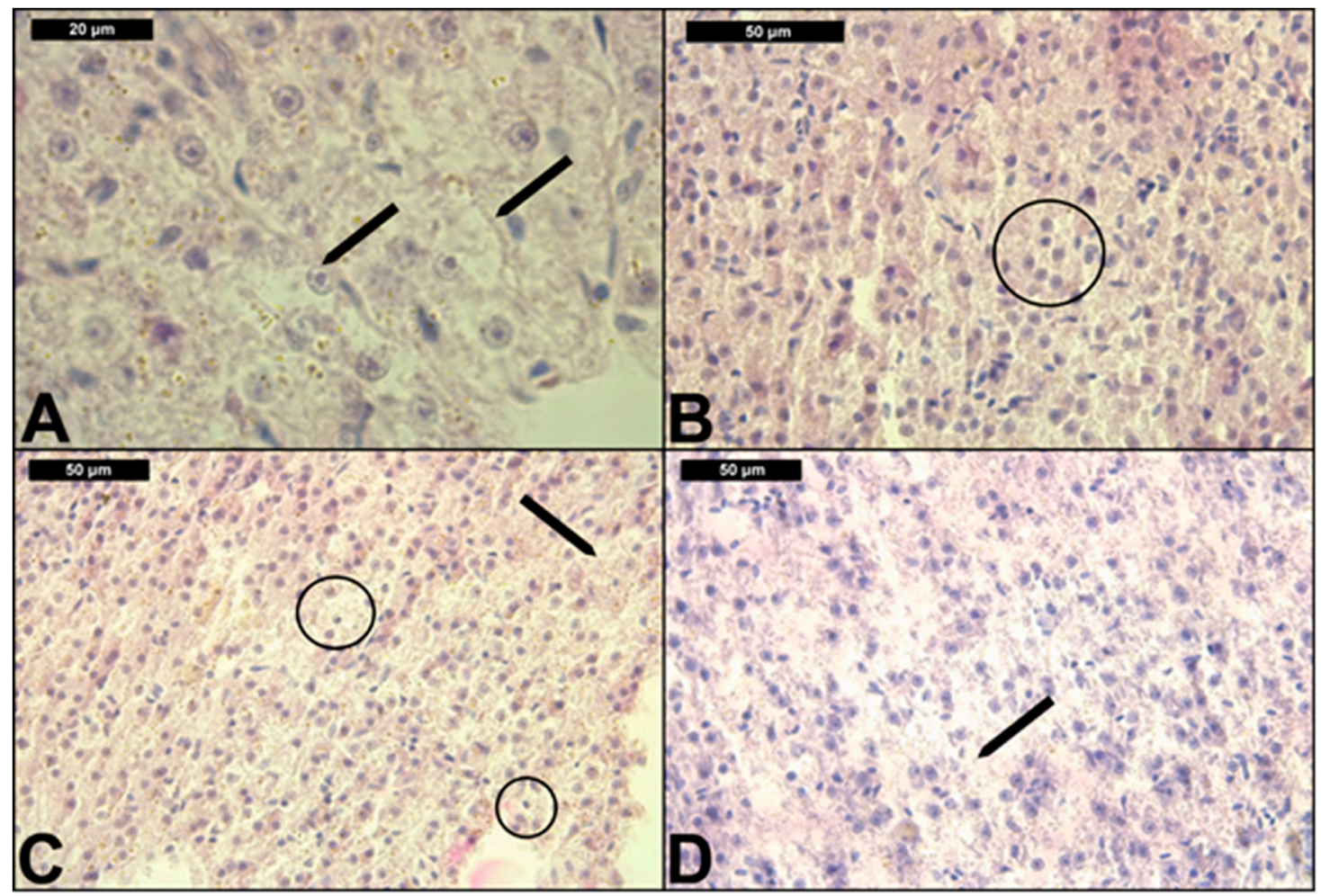

Figure 2. Histopathological alterations in the liver of common carp after the exposure with decreasing CPF concentrations based on Directive 2013/39/EU of the European Parliament and of the Council $(0.03 \mu \mathrm{g} / \mathrm{L})$. (A) Initial process of lipid accumulation (scale bar $20 \mu \mathrm{m}) \mathrm{H} \& \mathrm{E}$; (B) granular degeneration (scale bar $50 \mu \mathrm{m}$ ) H\&E; (C) necrosis (scale bar $50 \mu \mathrm{m}$ ) H\&E; (D) nuclear alterations-karyolysis (arrow) and karyopyknosis (scale bar $50 \mu \mathrm{m}) \mathrm{H} \& \mathrm{E}$. 
Table 2. Histopathological alterations in the liver of common carp after the exposure with decreasing CPF concentrations based on Directive 2013/39/EU of the European Parliament and of the Council.

\begin{tabular}{|c|c|c|c|c|c|c|c|c|}
\hline \multirow{2}{*}{$\begin{array}{l}\text { Reaction } \\
\text { Pattern }\end{array}$} & \multirow{2}{*}{$\begin{array}{l}\text { Functional } \\
\text { Unit of the } \\
\text { Tissue }\end{array}$} & \multirow{2}{*}{ Alteration } & \multirow{2}{*}{ Importance Factor } & \multicolumn{4}{|c|}{ Score Value } & \multirow{2}{*}{$\begin{array}{l}\text { Index for Each Group } \\
(0.009 ; 0.015 ; 0.03 \mu \mathrm{g} / \mathrm{L})\end{array}$} \\
\hline & & & & Control & $0.009 \mu \mathrm{g} / \mathrm{L}$ & $0.015 \mu \mathrm{g} / \mathrm{L}$ & $0.03 \mu \mathrm{g} / \mathrm{L}$ & \\
\hline \multirow[t]{2}{*}{$\begin{array}{c}\text { Circulatory } \\
\text { Disturbances * }\end{array}$} & Liver & Hyperaemia & $\mathrm{W}_{\mathrm{LC1}}=1$ & 0 & 0 & 2 & 2 & \multirow{2}{*}{$\begin{array}{l}\mathrm{I}_{\mathrm{LC}}=0 \\
\mathrm{I}_{\mathrm{LC}}=2 \\
\mathrm{I}_{\mathrm{LC}}=2\end{array}$} \\
\hline & & Intercellular oedema & & 0 & 0 & 0 & 0 & \\
\hline \multirow{9}{*}{$\begin{array}{l}\text { Regressive } \\
\text { Lesions* }\end{array}$} & \multirow{5}{*}{ Liver } & Granular degeneration & $\mathrm{W}_{\mathrm{LR} 1}=1$ & 1 & 2 & 2 & 2 & \multirow{9}{*}{$\begin{array}{c}\mathrm{I}_{\mathrm{LR}}=4 \\
\mathrm{I}_{\mathrm{LR}}=11 \\
\mathrm{I}_{\mathrm{LR}}=19\end{array}$} \\
\hline & & Deposits (lipids) & $\mathrm{W}_{\mathrm{LR} 3}=1$ & 0 & 0 & 0 & 0 & \\
\hline & & Nuclear alterations & $\mathrm{W}_{\mathrm{LR} 4}=2$ & 0 & 0 & 1 & 2 & \\
\hline & & Necrosis & $\mathrm{W}_{\mathrm{LR} 5}=3$ & 0 & 0 & 1 & 2 & \\
\hline & & Vacuolar degeneration & $\mathrm{W}_{\mathrm{LR6}}=2$ & 0 & 1 & 2 & 3 & \\
\hline & \multirow{4}{*}{$\begin{array}{l}\text { Interstitial } \\
\text { tissue }\end{array}$} & $\begin{array}{c}\text { Architectural and } \\
\text { structural alterations }\end{array}$ & $\mathrm{W}_{\mathrm{LR} 7}=1$ & 0 & 0 & 0 & 1 & \\
\hline & & Deposits & $\mathrm{W}_{\mathrm{LR} 8}=1$ & 0 & 0 & 0 & 0 & \\
\hline & & Nuclear alterations & $\mathrm{W}_{\mathrm{LR} 9}=2$ & 0 & 0 & 0 & 0 & \\
\hline & & Necrosis & $\mathrm{W}_{\mathrm{LR} 10}=3$ & 0 & 0 & 0 & 0 & \\
\hline \multirow{2}{*}{$\begin{array}{l}\text { Progressive } \\
\text { Lesions * }\end{array}$} & Liver & Hypertrophy & $\mathrm{W}_{\mathrm{LP} 1}=1$ & 0 & 1 & 1 & 2 & \multirow{2}{*}{$\begin{array}{l}\mathrm{I}_{\mathrm{LP}}=1 \\
\mathrm{I}_{\mathrm{LP}}=1 \\
\mathrm{I}_{\mathrm{LP}}=3\end{array}$} \\
\hline & $\begin{array}{l}\text { Interstitial } \\
\text { tissue }\end{array}$ & Hypertrophy & $\mathrm{W}_{\mathrm{LP2}}=1$ & 0 & 0 & 0 & 1 & \\
\hline \multirow[t]{3}{*}{ Inflammation * } & \multirow[t]{2}{*}{ Liver } & $\begin{array}{l}\text { Activation of the } \\
\text { reticuloendothelial system } \\
\text { in the parenchyma (RES) }\end{array}$ & $\mathrm{W}_{\mathrm{LI} 1}=1$ & 0 & 0 & 0 & 1 & \multirow{2}{*}{$\begin{array}{l}\mathrm{I}_{\mathrm{LI}}=0 \\
\mathrm{I}_{\mathrm{LI}}=0 \\
\mathrm{I}_{\mathrm{LI}}=3\end{array}$} \\
\hline & & Infiltration & $\mathrm{W}_{\mathrm{LI} 2}=2$ & 0 & 0 & 0 & 1 & \\
\hline & & Index organ & & $\mathrm{I}_{\mathrm{C}}=1$ & $\mathrm{I}_{0.009}=5$ & $\mathrm{I}_{0.015}=14$ & $\mathrm{I}_{0.03}=27$ & \\
\hline
\end{tabular}

* According to Bernet et al. [49], Saraiva et al. [50] and Zimmerli et al. [51]: Reaction index (circulatory disturbances ( $\left.\mathrm{I}_{L C}\right)$, regressive lesions ( $\left.\mathrm{I}_{\mathrm{LR}}\right)$, progressive lesions ( $\left.\mathrm{I}_{\mathrm{LP}}\right)$ and inflammation $\left(\mathrm{I}_{\mathrm{L}}\right)$ ) is calculated by the sum of multiplied importance factors and score values of the alterations of the corresponding reaction pattern. The sum of reaction indices of the organ is equivalent to the organ index (Io). Organ index values (Io) for: circulatory disturbances ( $\mathrm{I}_{\mathrm{LC}}$ ), regressive lesions ( $\mathrm{I}_{\mathrm{LR}}$ ), progressive lesions ( $\mathrm{I}_{\mathrm{LP}}$ ) and inflammation ( $\left.\mathrm{I}_{\mathrm{LI}}\right)$ calculated in order to equivalent to the organ index (Io). Organ index values (Io) for: circulatory disturbances $\left(\mathrm{I}_{\mathrm{LC}}\right)$, regressive lesions $\left(\mathrm{I}_{\mathrm{LR}}\right)$, progressive lesions $\left(\mathrm{I}_{\mathrm{LP}}\right)$ and inflammation $\left(\mathrm{I}_{\mathrm{LI}}\right)$ calculated in order to
classify the severity of the histological response. Index for each group shows the sum of the score value of the histological alterations corresponding to each reaction pattern at the different classify the severity of the histological response. Index for each group shows the sum of the score value of the histological alterations corresponding to each reaction pattern at the different
$\mathrm{CPF}$ concentrations $(0.009 ; 0.015 ; 0.03 \mu \mathrm{g} / \mathrm{L})$. Importance factor $(\mathrm{W})$ for: circulatory disturbances $\left(\mathrm{I}_{\mathrm{LC}}\right.$ ), regressive lesions $\left(\mathrm{I}_{\mathrm{LR}}\right)$, progressive lesions $\left(\mathrm{I}_{\mathrm{L}} \mathrm{P}\right)$ and inflammation $\left(\mathrm{I}_{\mathrm{LI}}\right)$ shows how big impact the histological alteration has on the fish; severity gradation scale (SGS): (0)—no histological alterations, which represented normal liver histological structure; (1)—mild histological alterations; (2)—-moderate histological alterations; (3)—pronounced histological alterations; (4)—severe histological alterations and (5)—very severe histological alterations. Importance factor: (1) - minimal pathological importance, the lesion is easily reversible when the toxicant exposure stops; (2) - moderate pathological importance, the lesion is reversible in most cases if the stressor is neutralized and (3)-marked pathological importance, the lesion is generally irreversible, leading to partial or total loss of the organ function. 
Table 3. Percentage of histopathological alterations in common carp liver after the exposure with decreasing CPF concentrations based on Directive 2013/39/EU of the European Parliament and of the Council.

\begin{tabular}{|c|c|c|c|c|c|c|}
\hline \multirow{2}{*}{\multicolumn{3}{|c|}{ Histopathological Alterations }} & \multicolumn{4}{|c|}{ Prevalence, $\%$} \\
\hline & & & \multirow{2}{*}{$\begin{array}{c}\text { Control } \\
0\end{array}$} & \multirow{2}{*}{$\begin{array}{c}0.009 \mu \mathrm{g} / \mathrm{L} \\
0\end{array}$} & \multirow{2}{*}{$\begin{array}{c}0.015 \mu \mathrm{g} / \mathrm{L} \\
32\end{array}$} & \multirow{2}{*}{$\begin{array}{c}0.030 \mu \mathrm{g} / \mathrm{L} \\
38\end{array}$} \\
\hline $\begin{array}{l}\text { Circulatory } \\
\text { Disturbances }\end{array}$ & Liver & Hyperaemia & & & & \\
\hline & & Intercellular oedema & 0 & 0 & 0 & 0 \\
\hline & Avera & & 0 & 0 & 16 & 19 \\
\hline \multirow{9}{*}{$\begin{array}{l}\text { Regressive } \\
\text { Lesions }\end{array}$} & \multirow{5}{*}{ Liver } & Granular degeneration & 11 & 36 & 41 & 47 \\
\hline & & Deposits (lipids) & 0 & 0 & 0 & 0 \\
\hline & & Nuclear alterations & 0 & 0 & 16 & 42 \\
\hline & & Necrosis & 0 & 0 & 21 & 36 \\
\hline & & Vacuolar degeneration & 0 & 17 & 36 & 47 \\
\hline & \multirow{4}{*}{$\begin{array}{l}\text { Interstitial } \\
\text { tissue }\end{array}$} & $\begin{array}{l}\text { Architectural and } \\
\text { structural alterations }\end{array}$ & 0 & 0 & 0 & 14 \\
\hline & & Deposits & 0 & 0 & 0 & 0 \\
\hline & & Nuclear alterations & 0 & 0 & 0 & 0 \\
\hline & & Necrosis & 0 & 0 & 0 & 0 \\
\hline \multicolumn{3}{|c|}{ Average, $\%$} & 1.2 & 5.9 & 12.7 & 20.7 \\
\hline \multirow{3}{*}{$\begin{array}{l}\text { Progressive } \\
\text { Lesions }\end{array}$} & Liver & Hypertrophy & 0 & 13 & 21 & 32 \\
\hline & $\begin{array}{l}\text { Interstitial } \\
\text { tissue }\end{array}$ & Hypertrophy & 0 & 0 & 0 & 12 \\
\hline & \multicolumn{2}{|c|}{ Average, \% } & 0 & 6.5 & 10.5 & 22 \\
\hline \multirow[t]{3}{*}{ Inflammation } & \multirow[t]{2}{*}{ Liver } & $\begin{array}{l}\text { Activation of the } \\
\text { reticuloendothelial } \\
\text { system in the } \\
\text { parenchyma (RES) }\end{array}$ & 0 & 0 & 0 & 25 \\
\hline & & Infiltration & 0 & 0 & 0 & 37 \\
\hline & \multicolumn{2}{|c|}{ Average, \% } & 0 & 0 & 0 & 31 \\
\hline
\end{tabular}

\subsection{Liver Enzymatic Activity}

We found an increase in the LDH specific activity with increasing insecticide concentrations. However, the LDH specific activity differed significantly among the different groups (ANOVA F $=22.33$; $p<0.001$ ) (Figure 3).

In addition, the statistical data showed that the ASAT specific activity differed significantly among the different groups (ANOVA F $=8.008 ; p<0.01$ ). The ALAT specific activity also differed significantly among the different groups (ANOVA $\mathrm{F}=6.345 ; p<0.01$ ) (Figure 4 ). 


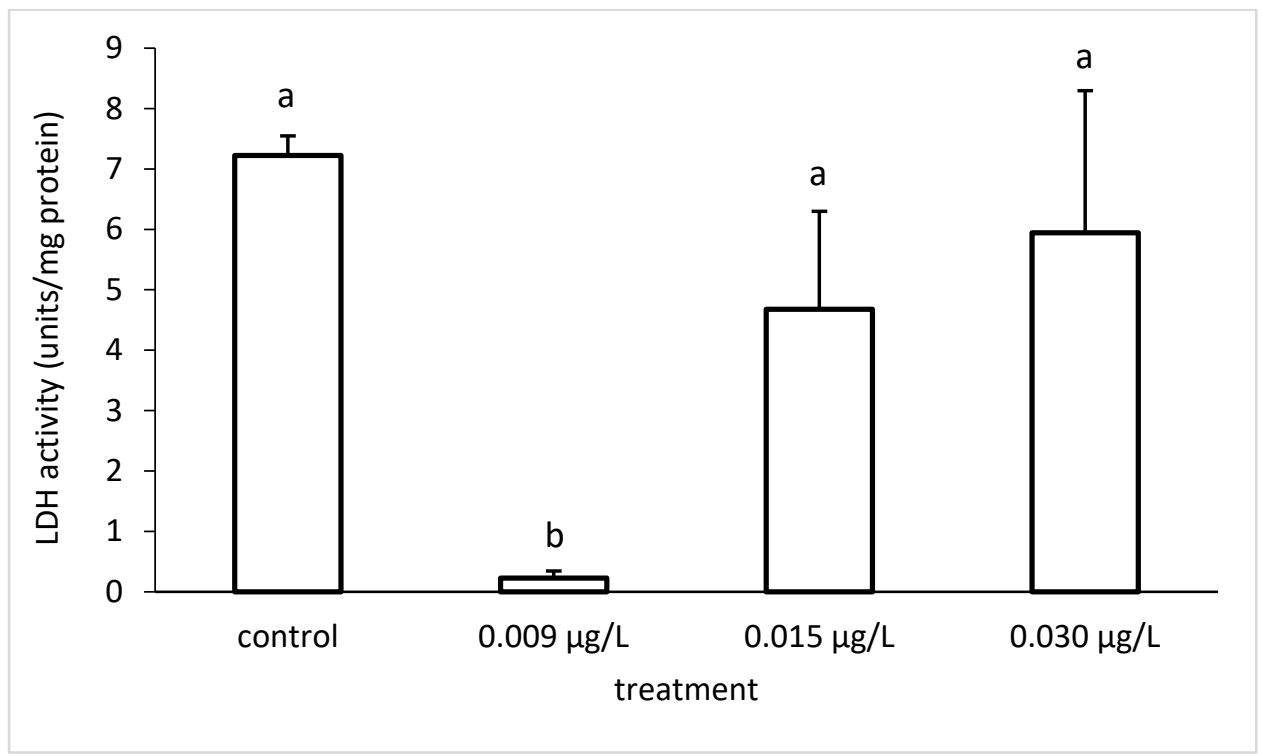

Figure 3. Lactate dehydrogenase (LDH) activity in common carp liver under different CPF exposures. Bars represent means \pm SD of the control and experimental groups. Different letters indicate significant differences among treatments $(p<0.05)$.

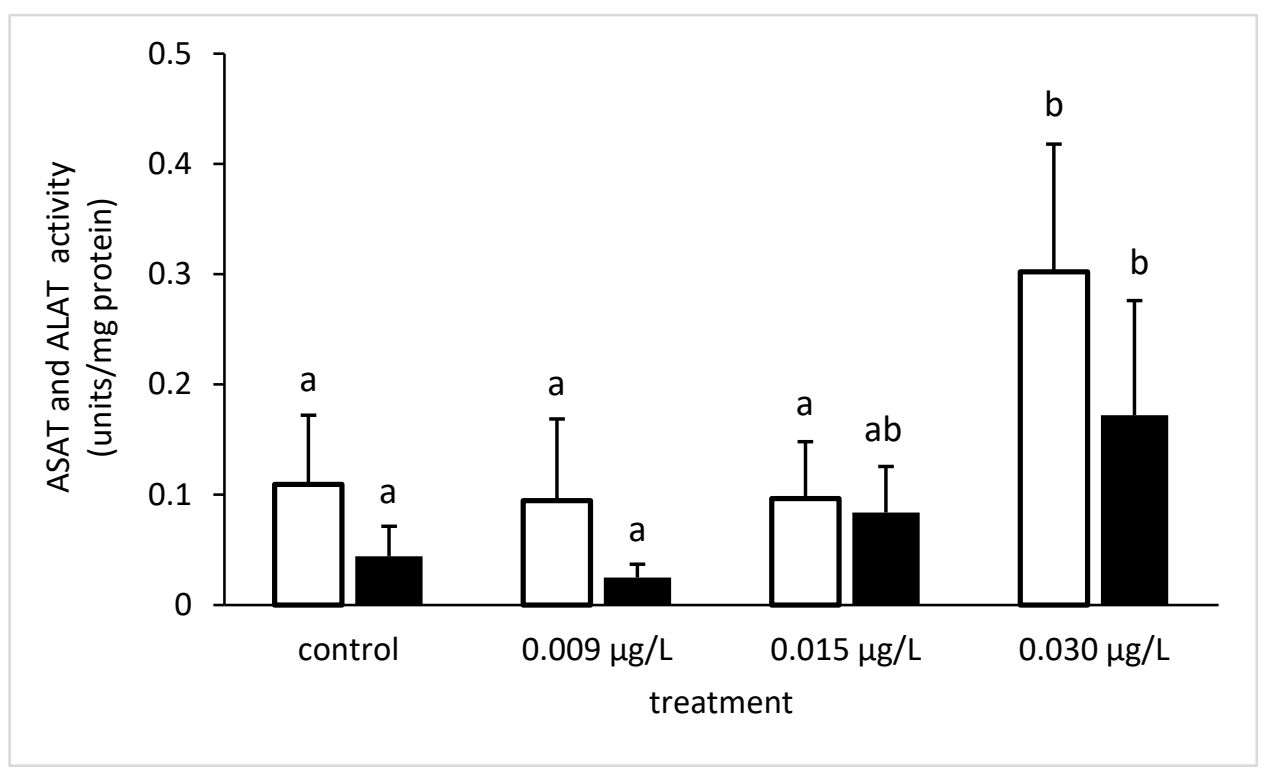

Figure 4. Aspartate aminotransferase (ASAT) (white bars) and alanine aminotransferase (ALAT) activity (black bars) in common carp liver under different CPF exposures. Bars represent means \pm SD of the control and experimental groups. Different letters indicate significant differences among treatments $(p<0.05)$.

On one hand, the ChE specific activity decreased compared to the control group (Figure 5), which confirmed the toxic potential of the tested insecticide in terms of enzymatic inhibition. However, the enzymatic activity did not differ significantly among the different groups (ANOVA F = 2.073; $p>0.05)$. 


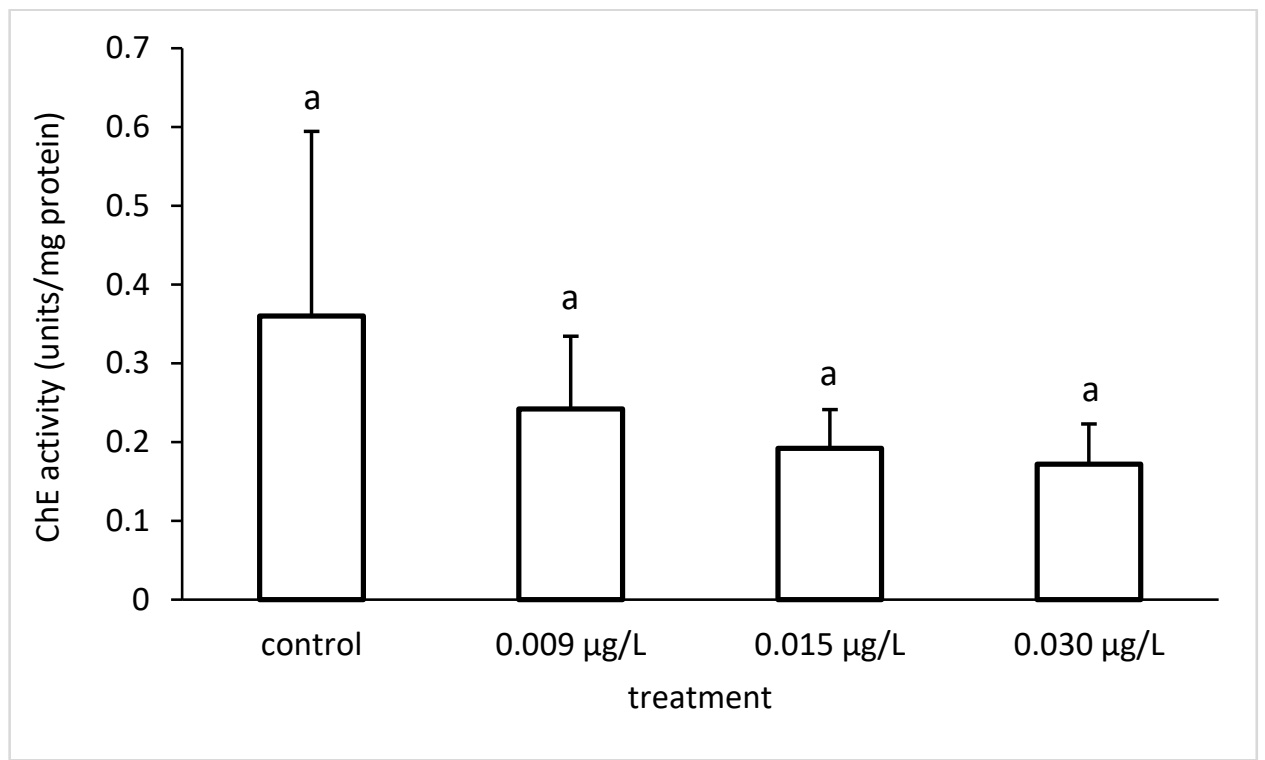

Figure 5. Cholinesterase (ChE) activity in common carp liver under different CPF exposures. Bars represent means \pm SD of the control and experimental groups; ' $a$ ' letter represents that there were no significant differences among treatments $(p>0.05)$.

Similar to the ChE, the activity of GPx was reduced regarding the control and the applied concentrations of CPF (Figure 6). The GPx specific activity differed significantly among the different groups (ANOVA F $=25.33 ; p<0.001)$.

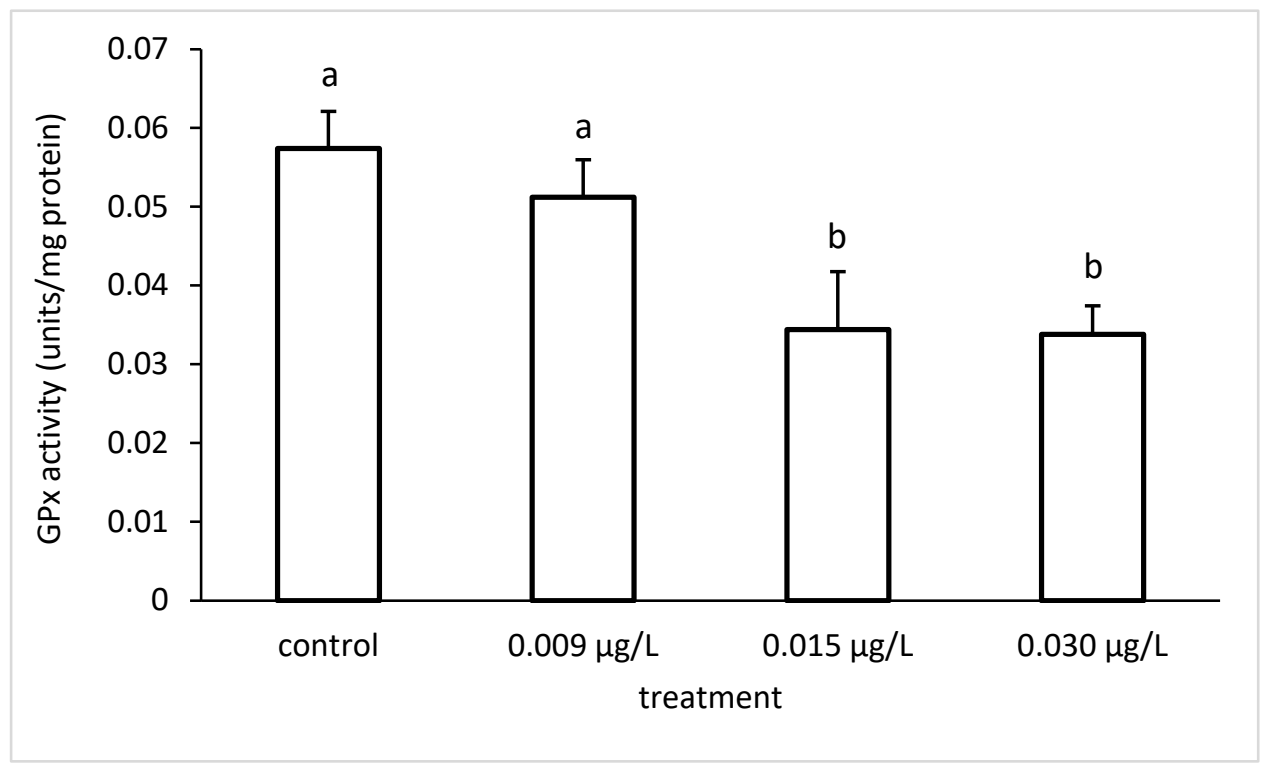

Figure 6. Glutathione peroxidase (GPx) activity in common carp liver under different CPF exposures. Bars represent means \pm SD of the control and experimental groups. Different letters indicate significant differences among treatments $(p<0.05)$.

On the other hand, the activity of CAT generally increased proportionately to the increased insecticide concentrations. However, the CAT specific activity differed significantly among the different groups (ANOVA F $=39.88 ; p<0.001$ ) (Figure 7). 


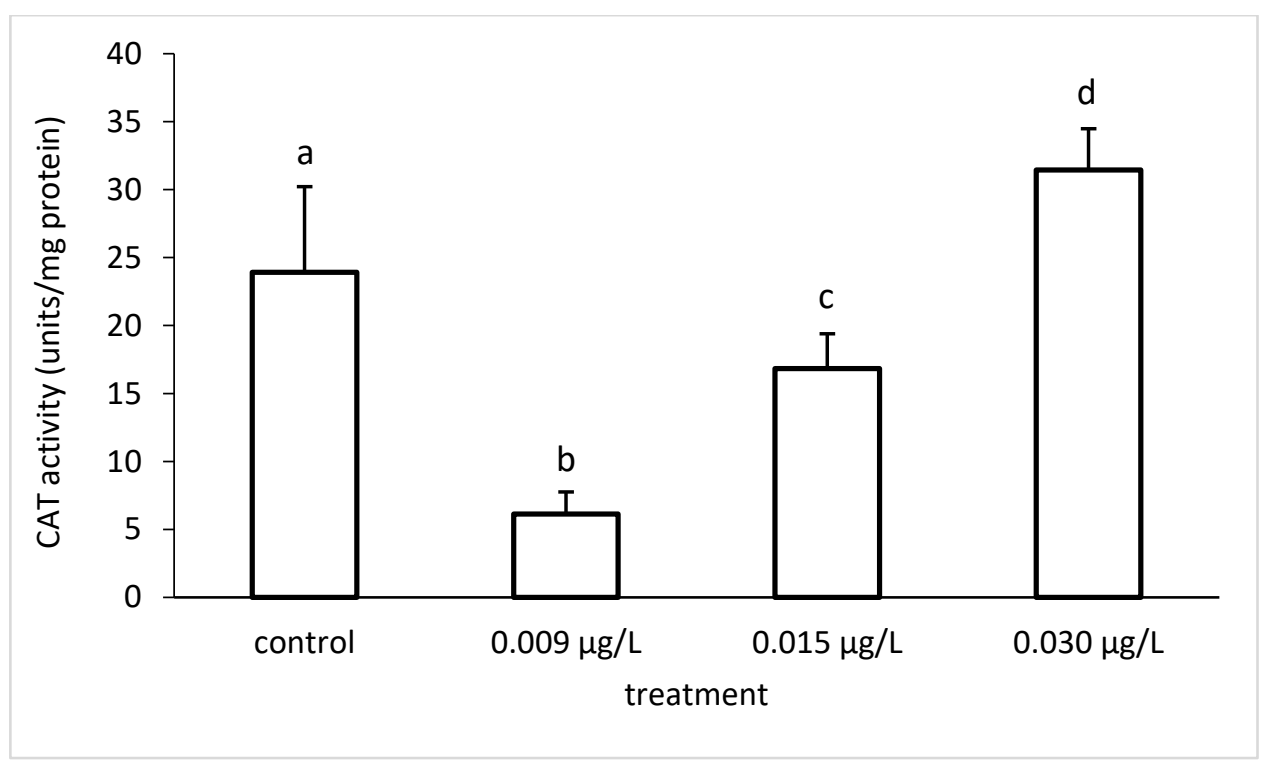

Figure 7. Catalase (CAT) activity in common carp liver under different CPF exposures. Bars represent means \pm SD of the control and experimental groups. Different letters indicate significant differences among treatments $(p<0.05)$.

With regard to the enzyme CAT, a lower activity was found at the lowest applied CPF concentration, which we think indicates a more active involvement of GPx, as both enzymes participate in the mechanism of antioxidant protection. In addition, the CAT specific enzymatic activity increased with the increasing pesticide concentrations. At the highest CPF concentration, the activity of CAT was higher than the control, which probably indicates the occurrence of oxidative stress, due to the accumulation of free oxygen radicals in the organism under CPF toxicity.

\section{Discussion}

The water quality parameters during the experiment were in accordance with FAO (1999) [59] and APHA (2005) [46], although there were differences among the experimental groups.

The histological changes in fish liver could serve as useful biomarkers that show the influence of toxic substances on the organism, due to the liver's main function in detoxification lipophilicity [60]. We agree with Xing et al. [8] and Deb and Das [61], who state that degeneration, pyknotic nuclei, fatty infiltration or total necrosis at different levels of expression, as a result of pesticide intoxication, could be established in the liver parenchyma. According to Bukhari et al. [62], the hepatic lesions are associated with the increased toxicant concentrations, which we confirmed in our study. In addition, the production of free radicals, lipid peroxidation and changes in the antioxidant state are vital factors for the toxic effects of pesticides on the liver histological structure [63]. According to Albañil Sánchez et al. [45], lipid degeneration in fish liver caused by pesticides leads to dysfunctions in the microsomal and mitochondrial systems of cell, which can lead to the inhibition of the synthesis of lipoproteins. As a result of both acute and chronic exposure to pesticides, the hepatic function is affected, resulting in a reduction of protein concentration [64], which, in turn, affects the liver tissue. We support the opinion of Velisek et al. [65], who highlighted that the toxic effects of pesticides could lead to overproduction of lipid peroxidation in various tissues, as well as in the liver, which causes histological alterations. In addition, reactive oxygen species (ROS) induce peroxidative damage in the liver, and this could be one of the molecular mechanisms of CPF toxicity, which we suggest needs further detailed research. We agree with Oruç and Üner [66], who state that the physiological changes in fish depend on the species specificity, the chemical characteristics of the pesticides, their concentration and the duration of the exposure period. According to Pereira Maduenho and Martinez [67], the most severe histological changes occur with increased cell and nuclear volume, which is associated with cytoplasmic and 
nuclear alterations, and biliary dysfunction with increased metabolic activity of the hepatocytes, which we confirmed in the present study. Similar to our study, Xing et al. [8] found varying degrees of hydropic degeneration, vacuolization, pyknotic nuclei and fatty degeneration due to $\mathrm{CPF}$, and atrazine exposure at concentrations close to LC50 of the tested pesticides. In parallel, changes in the enzymatic activity of CAT and GPx were also observed by the authors. Tilak et al. [68] observed similar alterations in the liver of Gibelion catla (Hamilton 1822) under the action of CPF. The pathological lesions included cytoplasm degeneration in the hepatocytes, atrophy, vacuolar degeneration, blood vessel destruction, necrosis and damage in the hepatocyte cell membrane, and pyknotic hepatocyte nuclei, which we also found in the liver of common carp exposed to CPF. Moreover, Mohamed [69] and Kostić et al. [70] described that the stasis of blood could be responsible for cellular degeneration and necrosis in the liver. In addition, sinusoidal congestion blocks blood from the hepatic artery and the interbiliary portal vein, which has to pass through the sinusoids on its way to the central vein. We support the opinion of Devi and Mishra [31], who consider that the parenchyma cytoplasmic and nuclear degeneration observed in the liver, as well as the vacuolization of the hepatocytes, is probably due to metabolic damage related to the exposure to CPF contaminated water. In our previous study [71], which involved glyphosate-based herbicide, the histological lesions in common carp liver also showed a different degree of expression, which increased in proportion to the increasing pesticide concentrations.

Overall, the observed histological changes in the common carp liver could be used as reliable biomarkers, which indicate the negative effects of the exposure to toxic substances in the environment. Although the liver is the primary organ of detoxification, the impact of pesticides such as CPF may change the ecological plasticity of fish to stress factors of the environment. In addition, abnormal hepatocytes can interfere with the normal metabolism, and thus disrupt fish health, or even cause fish death. Similarly to Devi and Mishra [31], we consider the studies on histological changes observed in fish liver, as well as in other tested organs (gills, spleen, kidney, muscle) to be an effective biological tool for assessing the health of fish populations, which, in turn, reflect the health of the entire aquatic ecosystem.

According to Banaee [24], Stoyanova et al. [71,72] and Yancheva et al. [52], LDH activity is usually related to cellular metabolic activity, and serves as the major enzyme between glycolysis and the citric acid cycle. LDH is an important enzyme, due to its function in the anaerobic pathway of energy production. According to the authors mentioned above, fish, under conditions of stress, need extra energy, thus, LDH is then involved in energy production via anaerobic metabolism. Our results suggest changes in the processes of glycolysis and glycogenogenesis; therefore, we found a decreased LDH activity at the lowest CPF concentration and an increased LDH activity at the other two, higher CPF concentrations. In general, LDH activity is a commonly used diagnostic tool and demonstrates an increase in anaerobic metabolism due to the depletion of energy and stress caused by environmental changes and the effect of different toxicants. Furthermore, we agree with Banaee [24], according to whom, alterations in the LDH activity are indicative for hepatic tissue damage, which serves as a diagnostic tool in toxicological studies.

According to Guptha et al. [25], the transaminases are a group of enzymes that elevate the activity of enzyme phosphorylase, which has a significant role in glycogenolysis, and also represents a major link between protein and carbohydrate metabolisms. We agree with Ghorpade et al. [26] that the increase in the activity of ALAT could be used as a more specific biomarker for acute toxicity, compared to ASAT activity. Moreover, the changes in the ALAT levels play an important role in the glucose-alanine cycle in the liver. Similar to the authors mentioned above, we found that, under conditions of stress caused by the CPF exposure, the elevated levels of ASAT and ALAT stimulate the process of gluconeogenesis and the mobilization of L-amino acids.

Overall, the most significant results from our study showed a decrease in the enzymatic activity of LDH and ALAT compared to the control. This tendency was most clearly established at the lowest CPF concentration. Thus, we suppose that an initial process of triglyceride accumulation in the hepatocytes started. This is probably due to the increased pyruvate in the liver cells. Hence, via the pyruvate 
dehydrogenase complex, the amount of Acetyl-CoA also increases. Furthermore, Acetyl-CoA is used for the synthesis of fatty acids and cholesterol. Therefore, the increased amount of fatty acids in the liver leads to increased triglyceride synthesis and hyperlipidemia associated with lipid infiltration in the hepatocytes $[52,71,72]$. Although we did not identify cells with typical fatty degeneration by the applied histological method with H\&E, morphological changes in the cytoplasm and the location of the nucleus of single cells were determined, which probably suggests the beginning of the initial process of lipogenesis (Figure 2A).

According to Payne et al. [73], ChE inhibition is used as a marker to prove contamination of aquatic ecosystems with organophosphorus compounds. In our study, we also measured a decreased $\mathrm{ChE}$ activity in the fish treated with $\mathrm{CPF}$, compared to the control. This activity was in an inverse relationship with the applied CPF concentrations, i.e., it was lower in the samples treated with higher insecticide concentrations. Therefore, we also recommend the use of $\mathrm{ChE}$ in multi-biomarker studies on the effects of pesticides on fish, and, more precisely, in risk assessment and monitoring programs. In addition, according to Assis et al. [74], the interaction between cholinesterases (ChEs) and pesticides lies behind the ability of the enzymes to signal inhibition processes several days or weeks after exposure, even when in low concentrations. We agree with the authors who state that the in vitro approach could gain more precision in the correlation between pesticide concentrations and the resulting inhibition.

We confirmed that changes in the activity of antioxidant enzymes in the fish organism could serve as a biomarker for the toxicity of organic contaminants in water, as stated by Ahmad et al. [75]. Similar to Yousafzai and Shakoori [76], we consider that the variations in the specific enzymatic activity in the tested samples compared to the control presents an indicator of the effects of pesticides on fish health. Oxidative stress due to pesticide effects can be used in the toxicological studies as a possible mechanism for chemically induced toxicity $[61,77,78]$. Furthermore, induced oxidative stress by organophosphorus substances causes depletion of mitochondrial energy (ATP), overuse of proteolytic enzymes and DNA fragmentation. Biological systems have mechanisms to counteract free radical damage in the organism. The main mechanisms include antioxidant enzymes defense, which neutralizes free radicals. Antioxidant enzymes, such as superoxide dismutase (SOD), catalase (CAT), glutathione peroxidase $(\mathrm{GRx})$, vitamin $\mathrm{C}$, vitamin $\mathrm{E}$ and beta-carotene represent the most important antioxidant protection in biological systems [79]. In general, the biomarkers of oxidative stress can be divided into two main groups: free radical biomarkers in biological systems and antioxidant protection factors $[80,81]$. In the first group, Slaninova et al. [37] include the presence of products resulting from damage to free oxygen radicals, i.e., the most commonly used products of lipid peroxidation. The biomarkers applied in the present study belong to the group of antioxidant protection factors. Narra et al. [82] observed a significant increase in CAT activity during a CPF exposure, while at the same time, the authors established a decrease in the enzymatic levels during a recovery period. In the present study, we also observed an increased activity of CAT at the highest applied insecticide concentration. This could possibly be an indicator of oxidative stress caused by the applied CPF concentration, which equals the annual average environmental quality standards (AA-EQS), according to the national and EU legislation regarding the Water Frame Directive.

Overall, we think that, at the lower applied CPF concentrations, the enzyme GPx becomes more active, while at the higher concentrations, it is CAT which is more active. Clasen et al. [83] observed oxidative damage in carp, due to the toxic action of a complex of organic pollutants under field conditions, and chronic exposure. The oxidative damage was expressed in an increase in lipid peroxidation in the liver, which, in turn, is an indicator of oxidative stress. Similar to our study, the authors observed an increase in the activity of CAT resulting from the toxic action of the applied toxicants and the inclusion of the antioxidant protection of the organism. Nunes et al. [84] observed alterations in the CAT enzymatic activity in common carp and zebra fish (Danio rerio Hamilton, 1822) under different concentrations of cypermethrin and CPF for $96 \mathrm{~h}$. The enzymatic activity in common carp decreased compared to the control group, whereas that in zebra fish showed an increase compared to the control. This in turn, confirms that the changes in the activity of the antioxidant enzymes 
depend on the concentrations of the applied toxicants, the time of exposure and the species specificity. Similar to our study, Narra et al. [82] also found that the GPx activity was significantly decreased during the CPF exposure. As stated by Guptha et al. [25], GPx alters the protection provided for the cellular and subcellular membranes from peroxidative damage by eliminating $\mathrm{H} 2 \mathrm{O} 2$. We agree with Slaninova et al. [37], who stated that a consistent decrease in antioxidant enzymes is due to the excessive generation of free radicals, most likely generated by CPF in our study.

We support the opinion of Yonar [85] that the decrease or increase in enzymatic activities can be explained either by their consumption and induction during the conversion of free radicals into less harmful or harmless metabolites, or, secondarily, by the direct inhibitory or stimulatory effect of ROS that may be caused by CPF in the present study.

\section{Conclusions}

Overall, the results showed that CPF alters the liver histological structure, causing degenerative and necrobiotic alterations, and necrosis, as well as changes in the circulatory system. In addition, CPF induces changes in the enzymatic activity of LDH, ASAT, ALAT, ChE, GPx and CAT. In summary, we can conclude that the use of multi-biological approaches in environmental monitoring is crucial for assessing aquatic pollution and its impact on ecosystems. In addition, we consider that complex experimental set ups, such as the present one, including histological and biochemical biomarkers, should be performed to better determine the toxic impact of pesticides on fish. These results can be used for the application of the EU Water Framework Directive for preventing and reducing aquatic contamination with priority organic substances in Bulgaria and other developing countries in the Balkans, as well as for implementing proper agricultural practices.

Author Contributions: Conceptualization, S.S., V.Y.; Methodology, S.S., V.Y., E.G., I.I., T.V., V.B.; Formal analysis, K.N.; Supervision, I.V.; Writing-review and editing, S.S., S.T., K.N., L.A., V.Y.; Funding acquisition, S.S., E.G., L.A., V.Y. All authors have read and agreed to the published version of the manuscript.

Funding: The National program "Young Researches and Postdocs, 2018" financed by the Ministry of Education and Science, Bulgaria, is highly appreciated. The authors also thank the Ministry for Education and Science, Bulgaria and The Scientific Research Fund for the financial support for project M26/3 (Scientific Fundamental Research for Young Scientists and Postdocs). Krisztián Nyeste was supported by the ÚNKP-20-4 New National Excellence Program of the Ministry for Innovation and Technology in Hungary. The research was also supported by the Higher Education Institutional Excellence Programme (NKFIH-1150-6/2019) of the Ministry of Innovation and Technology in Hungary, within the framework of the 4th thematic programme of the University of Debrecen.

Acknowledgments: We also thank the experts at the Regional Accredited Laboratory, Executive Environment Agency, Ministry of Environment and Water, Plovdiv, Bulgaria for providing the toxicant.

Conflicts of Interest: The authors declare no conflict of interest.

\section{References}

1. Adedeji, O.B.; Okocha, R.O. Overview of Pesticide Toxicity in Fish. Adv. Environ. Biol. 2012, 6, $2344-2351$. Available online: http://www.aensiweb.com/old/aeb/2012/2344-2351.pdf (accessed on 1 July 2012).

2. Rusyniak, D.; Nañagas, K. Organophosphate Poisoning. Semin. Neurol. 2004, 24, 197-204. [CrossRef]

3. Sharbidre, A.A.; Metkari, V.; Patode, P. Effect of methyl parathion and chlorpyrifos on certain biomarkers in various tissues of guppy fish, Poecilia reticulata. Pestic. Biochem. Physiol. 2011, 101, 132-141. [CrossRef]

4. Asselborn, V.; Fernández, C.; Zalocar, Y.; Parodi, E.R. Effects of chlorpyrifos on the growth and ultrastructure of green algae, Ankistrodesmus gracilis. Ecotoxicol. Environ. Saf. 2015, 120, 334-341. [CrossRef]

5. Kumar, U.; Berliner, J.; Adak, T.; Rath, P.C.; Dey, A.; Pokhare, S.S.; Jambhulkar, N.N.; Panneerselvam, P.; Kumar, A.; Mohapatra, S.D. Non-target effect of continuous application of chlorpyrifos on soil microbes, nematodes and its persistence under sub-humid tropical rice-rice cropping system. Ecotoxicol. Environ. Saf. 2017, 135, 225-235. [CrossRef]

6. Wood, B.; Stark, J.D. Acute toxicity of drainage ditch water from a Washington State cranberry-growing region to Daphnia pulex in laboratory bioassays. Ecotoxicol. Environ. Saf. 2002, 53, 273-280. [CrossRef] 
7. Marino, D.J.; Ronco, A. Cypermethrin and Chlorpyrifos Concentration Levels in Surface Water Bodies of the Pampa Ondulada, Argentina. Bull. Environ. Contam. Toxicol. 2005, 75, 820-826. [CrossRef] [PubMed]

8. Xing, H.; Li, S.; Wang, Z.; Gao, X.; Xu, S.; Wang, X. Oxidative stress response and histopathological changes due to atrazine and chlorpyrifos exposure in common carp. Pestic. Biochem. Physiol. 2012, 103, 74-80. [CrossRef]

9. Kida, M.; Ziembowicz, S.; Koszelnik, P. Removal of organochlorine pesticides (OCPs) from aqueous solutions using hydrogen peroxide, ultrasonic waves, and a hybrid process. Sep. Purif. Technol. 2018, 192, 457-464. [CrossRef]

10. Abdel-Moneim, A.M.; Al-Kahtani, M.A.; Elmenshawy, O. Histopathological biomarkers in gills and liver of Oreochromis niloticus from polluted wetland environments, Saudi Arabia. Chemosphere 2012, 88, 1028-1035. [CrossRef] [PubMed]

11. Hutchinson, T.; Shillabeer, N.; Winter, M.; Pickford, D. Acute and chronic effects of carrier solvents in aquatic organisms: A critical review. Aquat. Toxicol. 2006, 76, 69-92. [CrossRef] [PubMed]

12. Jin, X.; Zha, J.; Xu, Y.; Giesy, J.P.; Wang, Z. Toxicity of pentachlorophenol to native aquatic species in the Yangtze River. Environ. Sci. Pollut. Res. 2011, 19, 609-618. [CrossRef] [PubMed]

13. Marigoudar, S.R.; Nagarjuna, A.; Karthikeyan, P.; Mohan, D.; Sharma, K. Comparative toxicity of chlorpyrifos: Sublethal effects on enzyme activities and histopathology of Mugil cephalus and Chanos chanos. Chemosphere 2018, 211, 89-101. [CrossRef] [PubMed]

14. Kottelat, M.; Freyhof, J. Handbook of European freshwater fishes; Kottelat, Cornol, Switzerland and Freyhof: Berlin, Germany, 2007.

15. Georgieva, E.; Atanasova, P.; Velcheva, I.; Stoyanova, S.; Yancheva, V. Histochemical effects of "Verita WG" on glycogen and lipid storage in common carp (Cyprinus carpio L.) liver. Ecol. Balk. 2013, 5, 91-97.

16. Xu, P.; Zhang, X.; Wang, X.; Li, J.; Liu, G.; Kuang, Y.-Y.; Xu, J.; Zheng, X.; Ren, L.; Wang, G.; et al. Genome sequence and genetic diversity of the common carp, Cyprinus carpio. Nat. Genet. 2014, 46, 1212-1219. [CrossRef]

17. Schultz, S.; Koussoroplis, A.-M.; Watzke, J.; Kainz, M.J.; Changizi-Magrhoor, Z. Fish oil-based finishing diets strongly increase long-chain polyunsaturated fatty acid concentrations in farm-raised common carp (Cyprinus carpio L.). Aquac. Res. 2014, 46, 2174-2184. [CrossRef]

18. Sfakianakis, D.; Renieri, E.; Kentouri, M.; Tsatsakis, A. Effect of heavy metals on fish larvae deformities: A review. Environ. Res. 2015, 137, 246-255. [CrossRef]

19. Khan, M.N.; Shahzad, K.; Chatta, A.; Sohail, M.; Piria, M.; Treer, T. A review of introduction of common carp Cyprinus carpio in Pakistan: Origin, purpose, impact and management. Croat. J. Fish. 2016, 74, 71-80. [CrossRef]

20. Macklin, R.; Brazier, B.; Harrison, S.; Chapman, D.; Vilizzi, L. A review of the status and range expansion of common carp (Cyprinus carpio L.) in Ireland. Aquat. Invasions 2016, 11, 75-82. [CrossRef]

21. Vajargah, M.F.; Yalsuyi, A.M.; Hedayati, A.; Faggio, C. Histopathological lesions and toxicity in common carp (Cyprinus carpio L. 1758) induced by copper nanoparticles. Microsc. Res. Tech. 2018, 81, 724-729. [CrossRef]

22. Poet, T.S.; Wu, H.; Kousba, A.A.; Timchalk, C. In Vitro Rat Hepatic and Intestinal Metabolism of the Organophosphate Pesticides Chlorpyrifos and Diazinon. Toxicol. Sci. 2003, 72, 193-200. [CrossRef] [PubMed]

23. Mehta, A.; Verma, R.S.; Srivastava, N. Chlorpyrifos-induced DNA damage in rat liver and brain. Environ. Mol. Mutagen. 2008, 49, 426-433. [CrossRef] [PubMed]

24. Banaee, M.; Sureda, A.; Mirvaghefi, A.R.; Ahmadi, K. Biochemical and histological changes in the liver tissue of rainbow trout (Oncorhynchus mykiss) exposed to sub-lethal concentrations of diazinon. Fish Physiol. Biochem. 2012, 39, 489-501. [CrossRef] [PubMed]

25. Guptha, J.S.; Renuka, M.; Suneetha, Y.; Srinivasulu Reddy, M. Evaluation of antioxidant defence system during xenobiotic induced oxidative stress in freshwater fish Oreochromis mossambicus. Int. J. Fish Aquat. Stud. 2016, 4, 379-385.

26. Ghorpade, N.; Mehta, V.; Khare, M.; Sinkar, P.; Krishnan, S.; Rao, C.V. Toxicity Study of Diethyl Phthalate on Freshwater Fish Cirrhina mrigala. Ecotoxicol. Environ. Saf. 2002, 53, 255-258. [CrossRef]

27. Gültekin, F.; Delibas, N.; Yasar, S.; Kilinc, I. In vivo changes in antioxidant systems and protective role of melatonin and a combination of vitamin $\mathrm{C}$ and vitamin $\mathrm{E}$ on oxidative damage in erythrocytes induced by chlorpyrifos-ethyl in rats. Arch. Toxicol. 2001, 75, 88-96. [CrossRef] 
28. Zhang, J.; Shen, H.; Wang, X.; Wu, J.; Xue, Y. Effects of chronic exposure of 2,4-dichlorophenol on the antioxidant system in liver of freshwater fish Carassius auratus. Chemosphere 2004, 55, 167-174. [CrossRef]

29. Peixoto, F.; Alves-Fernandes, D.; Santos, D.; Fontaínhas-Fernandes, A. Toxicological effects of oxyfluorfen on oxidative stress enzymes in tilapia Oreochromis niloticus. Pestic. Biochem. Physiol. 2006, 85, 91-96. [CrossRef]

30. Mansour, S.; Mossa, A.-T.H. Lipid peroxidation and oxidative stress in rat erythrocytes induced by chlorpyrifos and the protective effect of zinc. Pestic. Biochem. Physiol. 2009, 93, 34-39. [CrossRef]

31. Devi, Y.; Mishra, A. Histopathological alterations in gill and liver anatomy of fresh water, air breathing fish Channa punctatus after pesticide Hilban ${ }^{\circledR}$ (Chlorpyrifos) treatment. Adv. BioRes. 2013, 4, 57-62.

32. Kunjamma, A.K.P.; Philip, B.; Bhanu, S.V.; Jose, J. Histopathological effects on Oreochromis mossambicus (tilapia) exposed to chlorpyrifos. J. Environ. Res. Dev. 2008, 2, 553-559.

33. Van Der Oost, R.; Beyer, J.; Vermeulen, N.P. Fish bioaccumulation and biomarkers in environmental risk assessment: A review. Environ. Toxicol. Pharmacol. 2003, 13, 57-149. [CrossRef]

34. Stentiford, G.D.; Longshaw, M.; Lyons, B.; Jones, G.; Green, M.; Feist, S.W. Histopathological biomarkers in estuarine fish species for the assessment of biological effects of contaminants. Mar. Environ. Res. 2003, 55, 137-159. [CrossRef]

35. Nagaraju, B.; Rathnamma, V.V. Histopathological changes in the gill and liver of freshwater fish Labeo rohita (Hamilton) exposed to Novaluron. Innoriginal. Int. J. Sci. 2014, 1, 16-18.

36. Ksheerasagar, R.L.; Hiremath, M.B.; Kaliwa, B.B. Impairment of hepatic biochemical contents and enzymes activities during carbosulfan intoxication in albino mice. Int. J. Multidiscip. Res. Dev. 2011, 1, 6-15.

37. Slaninova, A.; Smutna, M.; Modra, H.; Svobodova, Z. A review: Oxidative stress in fish induced by pesticides. Neuro Endocrinol. Lett. 2009, 30, 2-12.

38. Bantu, N.; Vakita, V.R.; Karra, S. Effect of Chlorantraniliprole on biochemical and certain biomarkers in various tissues of freshwater fish Labeo rohita (Hamilton). Environ. Ecol. Res. 2013, 1, 205-215. [CrossRef]

39. Kurutaş, E.B. The importance of antioxidants which play the role in cellular response against oxidative/nitrosative stress: Current state. Nutr. J. 2016, 15, 71. [CrossRef]

40. Yancheva, V.; Velcheva, I.; Georgieva, E.; Mollov, I.; Stoyanova, S. Chlorpyrifos induced changes on the physiology of common carp (cyprinus carpio Linnaeus, 1785): A laboratory exposure study. Appl. Ecol. Environ. Res. 2019, 17, 5139-5157. [CrossRef]

41. Kamrin, M.A. Pesticide Profiles: Toxicity, Environmental Impact, and Fate; Lewis Publishers: Boca Raton, FL, USA, 1997.

42. De Moura, F.R.; Brentegani, K.R.; Gemelli, A.; Sinhorin, A.P.; Sinhorin, V.D.G. Oxidative stress in the hybrid fish jundiara (Leiarius marmoratus $\times$ Pseudoplatystoma reticulatum) exposed to Roundup Original ${ }^{\circledR}$. Chemosphere 2017, 185, 445-451. [CrossRef]

43. Modesto, K.A.; Martinez, C.B. Roundup ${ }^{\circledR}$ causes oxidative stress in liver and inhibits acetylcholinesterase in muscle and brain of the fish Prochilodus lineatus. Chemosphere 2010, 78, 294-299. [CrossRef] [PubMed]

44. Santos, T.G.; Martinez, C.B. Atrazine promotes biochemical changes and DNA damage in a Neotropical fish species. Chemosphere 2012, 89, 1118-1125. [CrossRef] [PubMed]

45. Sánchez, J.A.A.; Klosterhoff, M.D.C.; Romano, L.A.; Pires, D.M. Histological evaluation of vital organs of the livebearer Jenynsia multidentata (Jenyns, 1842) exposed to glyphosate: A comparative analysis of Roundup ${ }^{\circledR}$ formulations. Chemosphere 2018, 217, 914-924. [CrossRef] [PubMed]

46. APHA. Standard Methods for Examination of Water and Wastewater, 21st ed.; American Public Health Association: Washington, DC, USA, 2005.

47. Rosseland, B.O.; Massabuau, J.-C.; Grimalt, J.; Hofer, R.; Lackner, R.; Raddum, G.; Rognerud, S.; Vives, I. Fish ecotoxicology: European mountain lake ecosystems regionalisation, diagnostic and socio-economic evaluation (EMERGE). In Fish Sampling Manual for Live Fish; Norwegian Institute for Water Research (NIVA): Oslo, Norway, 2003; pp. 1-7.

48. Gautier, J.-C. Drug Safety Evaluation: Methods and Protocols, Methods in Molecular Biology; Springer Science Business Media: Berlin/Heidelberg, Germany, 2011.

49. Bernet, D.; Schmidt, H.; Meier, W.; Burkhardt-Holm, P.; Wahli, T. Histopathology in fish: Proposal for a protocol to assess aquatic pollution. J. Fish Dis. 1999, 22, 25-34. [CrossRef]

50. Saraiva, A.; Costa, J.; Serrão, J.; Cruz, C.; Eiras, J.C. A histology-based fish health assessment of farmed seabass (Dicentrarchus labrax L.). Aquaculture 2015, 448, 375-381. [CrossRef] 
51. Zimmerli, S.; Bernet, D.; Burkhardt-Holm, P.; Schmidt-Posthaus, H.; Vonlanthen, P.; Wahli, T.; Segner, H. Assessment of fish health status in four Swiss rivers showing a decline of brown trout catches. Aquat. Sci. 2007, 69, 11-25. [CrossRef]

52. Yancheva, V. Toxicity of two organophosphorous pesticides on bighead carp (Aristichthys nobilis Richardson, 1845) liver. Appl. Ecol. Environ. Res. 2016, 14, 397-410. [CrossRef]

53. Bradford, M.M. A rapid and sensitive method for the quantitation of microgram quantities of protein utilizing the principle of protein-dye binding. Anal. Biochem. 1976, 72, 248-254. [CrossRef]

54. Vassault, A. Methods of Enzymatic Analysis; Academic Press: New York, NY, USA, 1983; pp. 118-126.

55. Reitman, S.; Frankel, S. A Colorimetric Method for the Determination of Serum Glutamic Oxalacetic and Glutamic Pyruvic Transaminases. Am. J. Clin. Pathol. 1957, 28, 56-63. [CrossRef]

56. Burtis, C.A.; Ashwood, E.R. Textbook of clinical chemistry. Eur. J. Clin. Chem. Clin. Biochem. 1992, 30, 162-170.

57. Wendel, A. Enzymatic Basis of Detoxication, 1st ed.; Academic Press: New York, NY, USA, 1980; p. 333.

58. Hundet, A.; Prabhat, B. Histopathological alterations in hepatopancreas of a carp fish, C. carpio due to endosulfan toxicity. Cibtech J. Zool. 2014, 3, 7-11.

59. FAO. The State of World Fisheries and Aquaculture 2020; Food and Agriculture Organization of the United Nations (FAO): Roma, Italy, 2020.

60. Cuevas, N.; Zorita, I.; Franco, J.; Costa, P.M.; Larreta, J.; Zuazo, N.C. Multi-organ histopathology in gobies for estuarine environmental risk assessment: A case study in the Ibaizabal estuary (SE Bay of Biscay). Estuar. Coast. Shelf Sci. 2016, 179, 145-154. [CrossRef]

61. Deb, N.; Das, S. Chlorpyrifos toxicity in fish: A Review. Curr. World Environ. 2013, 8, 77-84. [CrossRef]

62. Bukhari, A.S.; Mohamed, H.S.; Broos, K.; Stalin, A.; Singhal, R.K.; Venubabu, P. Histological variations in liver of freshwater fish Oreochromis mossambicus exposed to ${ }^{60} \mathrm{Co}$ gamma irradiation. J. Environ. Radioact. 2012, 113, 57-62. [CrossRef] [PubMed]

63. Sevgiler, Y.; Oruç, E.Ö.; Üner, N. Evaluation of etoxazole toxicity in the liver of Oreochromis niloticus. Pestic. Biochem. Physiol. 2004, 78, 1-8. [CrossRef]

64. Saravanan, M.; Kumar, K.P.; Ramesh, M. Haematological and biochemical responses of freshwater teleost fish Cyprinus carpio (Actinopterygii: Cypriniformes) during acute and chronic sublethal exposure to lindane. Pestic. Biochem. Physiol. 2011, 100, 206-211. [CrossRef]

65. Velisek, J.; Stara, A.; Kolárová, J.; Svobodová, Z. Biochemical, physiological and morfological responses in common carp (Cyprinus carpio L.) after long-term exposure to terbutryn in real environmental concentration. Pestic. Biochem. Physiol. 2011, 100, 305-313. [CrossRef]

66. Oruç, E. Özcan; Üner, N. Combined effects of 2,4-D and azinphosmethyl on antioxidant enzymes and lipid peroxidation in liver of Oreochromis niloticus. Comp. Biochem. Physiol. Part C Toxicol. Pharmacol. 2000, 127, 291-296. [CrossRef]

67. Maduenho, L.P.; Martinez, C.B. Acute effects of diflubenzuron on the freshwater fish Prochilodus lineatus. Comp. Biochem. Physiol. Part C Toxicol. Pharmacol. 2008, 148, 265-272. [CrossRef]

68. Tilak, K.S.; Koteswara Rao, D.; Veeraiah, K. Effects of chlorpyrifos on histopathology of the fish Catla catla. J. Ecotox. Environ. Monitor. 2005, 15, 127-140.

69. Mohamed, F.A.S. Histopathological studies on Tilapia zillii and Solea vulgaris from Lake Qarun, Egypt. World J. Fish Mar. Sci. 2009, 1, 29-39.

70. Kostić, J.; Kolarević, S.; Kračun-Kolarević, M.; Aborgiba, M.; Gačić, Z.; Paunović, M.; Višnjić-Jeftić, Ž.; Rašković, B.; Poleksić, V.; Lenhardt, M.; et al. The impact of multiple stressors on the biomarkers response in gills and liver of freshwater breams during different seasons. Sci. Total Environ. 2017, 601, 1670-1681. [CrossRef] [PubMed]

71. Stoyanova, S.; Yancheva, V.; Iliev, I.; Vasileva, T.; Bivolarski, V.; Velcheva, I.; Georgieva, E. Glyphosate induces morphological and enzymatic changes in common carp (Cyprinus carpio L.) liver. Bulg. J. Agric. Sci. 2015, 21, 409-412.

72. Stoyanova, S. Biochemical, histological and histochemical changes in Aristichthys nobilis Rich. Liver exposed to thiamethoxam. Period. Biol. 2016, 118, 29-36. [CrossRef]

73. Payne, J.; Mathieu, A.; Melvin, W.; Fancey, L. Acetylcholinesterase, an old biomarker with a new future? Field trials in association with two urban rivers and a paper mill in Newfoundland. Mar. Pollut. Bull. 1996, 32, 225-231. [CrossRef] 
74. Assis, C.R.D.; Bezerra, R.S.; Carvalho, L.B., Jr. Fish cholinesterases as biomarkers of organophosphorus and carbamate pesticides, pesticides in the modern world. In Pests Control and Pesticides Exposure and Toxicity Assessment; Stoytcheva, M., Ed.; InTech: London, UK, 2011; ISBN 978-953-307-457-3.

75. Ahmad, I.; Hamid, T.; Fatima, M.; Chand, H.S.; Jain, S.K.; Athar, M.; Raisuddin, S. Induction of hepatic antioxidants in freshwater catfish (Channa punctatus Bloch) is a biomarker of paper mill effluent exposure. Biochim. et Biophys. Acta (BBA) Gen. Subj. 2000, 1523, 37-48. [CrossRef]

76. Yousafzai, A.M.; Shakoori, A.R. Hepatic response of a fresh water fish against aquatic pollution. Pak. J. Zool. 2011, 43, 209-221.

77. Akhgari, M.; Abdollahi, M.; Kebryaeezadeh, A.; Hosseini, R.; Sabzevari, O. Biochemical evidence for free radical induced lipid peroxidation as a mechanism for subchronic toxicity of malathion in blood and liver of rats. Hum. Exp. Toxicol. 2003, 22, 205-211. [CrossRef]

78. Abdollahi, M.; Ranjbar, A.; Shadnia, S.; Nikfar, S.; Rezaie, A. Pesticides and oxidative stress: A review. Med. Sci. Monit. 2004, 10, 141-147.

79. Sies, H. Oxidative stress: Oxidants and antioxidants. Exp. Physiol. 1997, 82, 291-295. [CrossRef]

80. Di Giulio, R.T.; Meyer, J.N. Reactive oxygen species and oxidative stress. In the Toxicology of Fishes; Di Giulio, R.T., Hinton, D.E., Eds.; CRC Press, Taylor and Francis Group: Boca Raton, FL, USA, 2008; pp. $273-324$.

81. Uchendu, C. The organophosphate, chlorpyrifos, oxidative stress and the role of some antioxidants: A review. Afr. J. Agric. Res. 2012, 7, 2720-2728. [CrossRef]

82. Narra, M.R.; Rajender, K.; Reddy, R.R.; Murty, U.S.; Begum, G. Insecticides induced stress response and recuperation in fish: Biomarkers in blood and tissues related to oxidative damage. Chemosphere 2017, 168, 350-357. [CrossRef] [PubMed]

83. Clasen, B.; Loro, V.L.; Murussi, C.R.; Tiecher, T.L.; Moraes, B.; Zanella, R. Bioaccumulation and oxidative stress caused by pesticides in Cyprinus carpio reared in a rice-fish system. Sci. Total Environ. 2018, 626, 737-743. [CrossRef] [PubMed]

84. Nunes, M.E.; Müller, T.E.; Murussi, C.; Amaral, A.M.D.; Gomes, J.L.; Marins, A.T.; Leitemperger, J.; Rodrigues, C.C.; Fiuza, T.L.; Costa, M.D.; et al. Oxidative effects of the acute exposure to a pesticide mixture of cypermethrin and chlorpyrifos on carp and zebrafish-A comparative study. Comp. Biochem. Physiol. Part C Toxicol. Pharmacol. 2018, 2018, 48-53. [CrossRef] [PubMed]

85. Yonar, M.E. Chlorpyrifos-induced biochemical changes in Cyprinus carpio: Ameliorative effect of curcumin. Ecotoxicol. Environ. Saf. 2018, 151, 49-54. [CrossRef] [PubMed] 